\title{
TEACHING READING AND CHANGING A LIFE: MIHLALI'S STORY
}

\author{
Renee Nathanson \\ Stellenbosch University
}

This article provides a narrative account of a literacy intervention I provided for an isiXhosa boy in Grade 1 who was struggling to read and write. The article first discusses the assumptions on which the intervention was based. These are: learning to read is a constructive rather than a mechanical process; educators who teach reading need to recognise the complexity of the reading process from the beginning of instruction, because even young children need to orchestrate complex mental operations when they start learning to read; and instruction should be based on close and systematic observation of what a child can do as a reader and writer and it should provide massive opportunities to read and write continuous texts. Next, the article explains how these principles were put into practice in the intervention. The aim of the article is to describe the theoretical principles underlying a oneon-one intervention based on the research undertaken by a core group of Reading Recovery theorists. It explains how that reading failure can be overcome through teaching that supports strategic reading. Its overall purpose is to contribute to an existing body of knowledge by providing insights that can help low-achieving readers make accelerated progress and catch up with their peers.

Keywords: Literacy intervention, reading strategies, writing process, complex theory, continuous texts, text gradient, constructive processes, Reading Recovery.

\section{INTRODUCTION}

'It all started with you, Makhulu, ${ }^{1}$ it all started with you'.

With these words, Nozi handed me her son's school report, clearly proud of her son's achievement. 'If it weren't for your help', she continued, 'Mihlali wouldn't be going to grade six now.' Nozi smiled brightly. After a troublesome and stressful start to his school career, Mihlali had passed Grade 5. I smiled back, genuinely pleased that I had had a hand in his success. It was something I will always feel good about. One thing I am certain about is that, without the early literacy intervention I provided, Mihlali would have been one of many instructionally disadvantaged children whose failing career paths were determined in those early years at school.

I thought back to the first time I became aware that Mihlali was struggling at school. His mother, Nozi, usually cheerful and optimistic, approached me to help him, distraught that her son was failing Grade 1 for the second time in a row. I considered the pros and cons: I knew I had the theoretical knowledge and practical experience to help him, but it was already midyear, and he was on his way to failing Grade 1 for the second time. I lived some distance away and worked full-time. I had a family and grandchildren. The only available time I had was over the weekend. Besides, reading interventions should be conducted more often than once a week. Because I knew Nozi, I offered my help over the weekend. 


\section{A ONE-ON-ONE INTERVENTION FOR MIHLALI}

I started the first reading intervention session with Mihlali on 21 May 2012, when he was redoing Grade 1 for the second time. Although much time has passed between the intervention and the writing of this article, the work I am currently doing with struggling readers convinces me that there is an urgent need for the kind of intervention described in this article. Pinnell, Fried and Estice's (1991: 12) research and my own experience indicate that the reading process can start going wrong for children in their first year of school. If children develop inefficient reading strategies during this formative stage of learning, they are likely to continue struggling in the years ahead. Delaying intervention, means that children are likely to accumulate years of failure before special help is considered in the form of complementary teaching (Clay, 1991a: 18). Mihlali's case highlights the value of early intervention, because learning to read enabled him to progress to Grade 6. Since I know Mihlali and his mother, telling his story allows me to share the experience I have gained in helping struggling readers in a more personal, memorable and interesting way.

\section{ASSESSING MIHLALI'S BASELINE READING LEVEL}

At the start of the intervention, my aim was to find out what Mihlali had learned regarding early concepts about print and what level books he could read independently. Children who have had rich literacy experiences in the home and at school usually have some well-defined ideas about how print is organised and used to express 'meaning'. They have developed concepts such as where to begin reading, which direction print flows and how organisational structures and illustrations support meaning. They have a repertoire of books they know well. If children come to school with some learning in each of these areas, their classroom programme should help round out their early learning (Clay, 1991a: 44). The first observation I recorded after asking Mihlali to read a beginner level book (i.e. Level A) was:

Journal entry: 21/05. At this point in time, he seems to have no idea what reading text is. He clearly finds reading unpleasant. He appears very uncomfortable and ill at ease and avoids looking at printed text. He stares at the ceiling, fidgets and seems 'trapped'. He is confused about what reading is. He points to the picture and tries to 'read the picture' instead of the text. He doesn't know where to start or what to do. He is unable to practice 1-to-1 matching (i.e. unable to match one spoken word with one printed word). Reading is punishment for him.

From the onset it was clear that Mihlali still had to learn some of the basic foundational information about reading and writing, for example, that reading text means paying attention to printed words, not generating one's own text from the pictures, how pictures and print work together to aid understanding, how letters and words work in general and in detail, and how to use all this information in a smoothly orchestrated process (Clay, 2002: 320-323). His negative attitude toward reading was perturbing, because students who do not like reading tend to have the lowest average reading achievement (Caine, 2008; PIRLS, 2006).

It was also clear that Mihlali's reading programme at school did not support his understanding of what the reading process involved. Neither did it foster a love for reading. A review of his homework sheets and reading materials indicated that the classroom reading programme took a phonics-based approach to reading instruction, for example, learn all single sounds; word building: -at, -an, -ag. This has practical day-to-day repercussions if one considers how much time is allocated to learning discrete skills at the expense of teaching children to read and to 
think about what they are reading. Likewise, the reading materials used in Mihlali's school showed a basal, piecemeal view, which fragmented the reading task into decontextualised, isolated portions of text. Due to a shortage of books, reading was taught using photocopied pages from basal readers, for example, Fluff, Nip, Pam, Dick. Here is Dick. Here is Pam. Here comes Nip. These basal readers were handed out to children one page at a time, thereby depriving them of opportunities to develop a sense of story, because they did not get a chance to read a complete story in one sitting. There was also nothing inherently interesting in these basal reading books to inspire children to want to read. Moreover, providing the same book for all readers in a class ignores the fact that children have different interests and they read and progress at different levels and rates.

Shortage and inefficient use of reading resources continue to be a problem in many lowperforming South African schools, with serious consequences for learners. In addition, skills training with boring and repetitive tasks is likely to disengage children from wanting to read and learn (Nair, 2017). Mihlali's low reading achievement was partly due to lack of access to real story books and interesting reading materials, which negatively affected his self-esteem and motivation. Considerable research has shown that children with high self-esteem about themselves as readers typically are better readers (PIRLS, 2006: 20).

Clay (1993: 7) points out that reading and writing difficulties have a large learned component, limiting school learning and getting worse if left untreated. After one and a half years at school, Mihlali was very much at risk of failing Grade 1 for the second time. There was no time to waste. More of the same programme was not going to help him make the gains he needed to progress to Grade 2. In order to catch up, he needed an intervention based on a different approach, one that would accelerate his learning and help him clear up the confusions he had developed about the nature of reading.

\section{THEORY AND RESEARCH METHODOLOGY FOR THE INTERVENTION}

Mihlali's intervention can be described as a case study which allowed me to adopt the role of observer and to capture detailed, in-depth information from one participant (Plowright, 2011: 25). Using direct observation and keeping detailed records of Mihlali's reading, writing and non-verbal behaviours were key features of the intervention, which aimed to help Mihlali make accelerated progress in reading and writing. The measure I used for demonstrating progress was a running record, which assesses how a child initiates problem-solving processes when reading continuous texts. It also plots the highest level of book on a gradient of text difficulty that a child can read at or above 90 percent accuracy. Given that Mihlali's mother asked me to conduct the intervention and that I was granted permission to publish my findings by all parties involved, the research was morally and ethically acceptable.

Because children are diverse in their responses to print, I used an instructional framework that helped me structure my thinking and teaching activities, but that did not dictate content (Plowright, 2011: 3). This enabled me to design an intervention that suited Mhilali's responses to the intervention. As such, it was not a pre-scripted, packaged programme. It was developed from an established theory base and from research undertaken by a core group of theorists (e.g., Block \& Duffy, 2008; Clay, 1991a, 2005, 2006; Fountas \& Pinnell, 2009; Weaver, 1998), as well as from my experience in teaching trainee teachers and in working with readers who were not making sufficient progress in reading. It was constructed around a number of key principles that allow children to make rapid progress and that can be applied to other, similar interventions. These principles are outlined below. They call popular theories 
and assumptions into question (e.g., waiting for 'readiness' to arrive, thereby delaying opportunities for much needed help; believing that low scores on assessments of early literacy reflect differences in abilities, rather than learned achievements; and insisting that children have to master letter-sound correspondences and core sight words before they can start reading and writing continuous texts). As explained below, they differ from traditional programmes that emphasise part-centred approaches to reading in important ways.

First, literacy instruction is founded on a complex theory of literacy processing, which views learning to read as a constructive rather than mechanical process (Clay, 1991a: 325-329). This view contends that it is vital for educators to recognise the complexity of the reading process from the beginning of instruction, because even young children need to orchestrate complex mental operations when they start learning to read. A complex theory views reading as an interactive set of parallel processes in which the reader has to learn to attend simultaneously to different levels in text (e.g., syntactic, semantic and orthographic levels) (Block \& Parris, 2008; Nathanson, 2011; Rumelhart \& McClelland, 1986). This contrasts with traditional programmes that over-emphasise simplistic, part-centred approaches, which require learners to memorise items of knowledge, such as letter, sound and word knowledge, with the result that many children fail to construct the necessary links between various items of knowledge. A complex theory differs from part-centred approaches in the emphasis it places on an individual's efforts to construct meaning through the use of the individual's 'unique constellation of prior knowledge, experience, background and social context' (Weaver, 1994: 57).

Second, instruction is based on close and systematic observation of what a child can do as a reader and writer. It draws from Clay's work in global educational literacy (1975-2015), which focuses on proficiency rather than deficiency (Fountas \& Pinnell, 2006: 364). Clay studied how successful readers read and then used that information to help struggling readers. She rejected simplistic theories based on part-centred approaches to learning to read and worked against the idea of diagnosing and treating deficits (Fountas \& Pinnell, 2006: 366). By working from children's strengths and paying particular attention to what a child can do, no time is wasted teaching anything the child already knows. It allows teachers to make instructional decisions specific to a child's learning needs. Clay (1993: 4) points out that systematic observation involves more than listening to children read; it involves attending to how the child is working with print during reading and then using that information to assist the child in developing effective strategies for working on text. This type of systematic observation contrasts sharply with several practices, such as casual or subjective observations, or judgemental conclusions based on fleeting observations while listening to children read (Clay, 2001: 29).

Specific teaching interactions based on close observation are essential in promoting individual learning and enabling children to make faster progress (Clay, 2002; Fountas \& Pinnell, 2009). While a child is reading, the teacher observes and records reading behaviours, such as substitutions, insertions and self-corrections, as well as the child's use of cues, such as meaning, syntax, letter-sound correspondences and other visual information in print (Pinnell et al., 1991:15). Through close observation, teachers become more articulate about how a particular child is using knowledge to solve problems in texts, and more aware of keeping instruction in line with what the child can actually do (Clay, 1993). Such an approach encourages teachers to question and think about their theories of knowledge and learning, because it involves them in an intensive process of observation, analysis and reflection (Costa, 2001: 80; Fountas \& Pinnell, 2006: 365). The view that knowledge is a constructive, 
problem-solving process contrasts sharply with the traditional idea of knowledge as content that learners need to absorb mentally so that they can demonstrate how well they can do this by means of assessment (Bolstad, Gilbert, McDowall, Bull, Boyd \& Hipkins, 2012: 4; Costa, 2001: x).

Third, literacy instruction should provide massive opportunities to read and write continuous texts. Hence, from the beginning of instruction, children read whole stories and high-quality non-fiction texts (i.e., 'little books'). Thus, children develop a sense of story, which supports comprehension. Contrived texts with strictly controlled vocabulary are avoided, because they are boring and they distort the expectations children have of how language works. Rather, the intervention makes use of the frequency principle, namely, that there is natural word control in language, which enables children to gain control of high-frequency words through extensive reading and authentic writing (Clay, 2001; Pinnell \& Fountas, 2011). This conflicts with the view that children have to master letter-sound correspondences and core sight words before they can start reading and writing authentic texts.

Overall, the research base supports the use of interesting trade or little story books that can be read from beginning to end in one reading lesson. Block and Duffy (2008: 25) found that the use of 'little books' in reading 'produced significantly higher comprehension scores than workbooks or extended basal texts treatments'. Furthermore, these findings hold true irrespective of students' home language, ethnicity, ability level and grade level (Block \& Duffy, 2008: 26). The criteria of progress are whether the child can read texts with a problemsolving approach which allows him/her to understand the passage and which makes his/her reading strategies effective, not whether he/she can decode new words independently.

The complex theory on which the intervention for Mihlali was based asserts that children who are learning to read and write continuous texts use those texts to help them build the same kinds of neural processing systems which successful readers use as they read. It also claims that comprehension is a matter of being strategic, not of knowing individual strategies or progressing through a scope and sequence of decoding activities (Block \& Duffy, 2008; Cartwright, 2008; Clay, 2001). Block and Duffy (2008: 29) explain that comprehension is a flexible, strategic process of predicting, monitoring and repredicting in a continuous cycle, stating that the entire strategic process must be in place for comprehension to occur. This means that 'comprehension strategies cannot be described as a scope and sequence in the way we think about decoding skills' (Block \& Duffy, 2008: 29). It implies that comprehension is best taught when children read continuous texts, for example, 'little books', from the start of instruction, because this enables children to construct early reading behaviours that become a network of strategies for reading increasingly challenging texts (Fountas \& Pinnell, 2009; Clay, 2001). Similarly, Clay (2001: 134-136) offers a description of cognitive flexibility, one in which skilled comprehenders flexibly coordinate multiple cues, such as semantic, syntactic and graphophonic cues. She questions reading instruction based solely on accurate decoding, pointing out that skill-based reading and writing programmes may cause many children to focus inflexibly on phonological aspects of words rather than on meaning, which is detrimental to developing comprehension.

Deford (1991) and Rodgers (2008) theorise that writing plays a critical role early in a child's reading development, because of the reciprocal nature of the reading and writing processes. Likewise, Clay (2001: 18) emphatically states that literacy programmes that do not include daily writing severely limit children's opportunities to learn and contribute to slower overall progress. Based on the view that reading and writing are concurrent sources of literacy 
learning, letter-sound relationships are not taught as a 'lead-in' to writing or reading (Clay, 2002: 12). Instead, children are encouraged to write their own messages from the beginning of instruction. The teacher does not control what the child is allowed to write, but rather teaches the child to hear and analyse sound sequences and to write them. Writing helps children become phonologically analytic about words, because it requires them to pay attention to visual cues and to construct each word, letter by letter. Less time is spent on drill, practice, copying and filling in worksheets, and more time on teaching children to use knowledge of words, letter-sound relationships and spelling patterns in reading and writing.

To summarise, in teaching both first and second language speakers to read and write, a teacher works from a complex theory of the reading and writing processes and focuses on teaching strategies to promote independent learning (Clay, 2010; McCarrier, Fountas \& Pinnell, 2000). It is evident that a theory of reading continuous texts cannot arise from a theory of word reading because it involves the integration of many behaviours that are not explained in a theory of reading words (Clay, 2001: 11-12).

In conclusion, if an intervention for struggling readers exchanges basal texts, which contain a predetermined sequence of items to be learned, for a book-based approach, beginner readers cannot be expected to be able to read any book, irrespective of vocabulary, semantic and syntactic complexities. They need a starting point and instruction on how to approach the reading task. It is therefore important to start with little story books at beginner level that have supporting characteristics, such as enlarged type fonts and spacing, consistent placement of print, memorable and repetitive language patterns, illustrations that match the text closely, familiar objects and natural language patterns. It is equally important to make use of a text gradient that ensures readers have access to enabling texts at an appropriate level (Hornsby, 2000; Petersen, 1991). This means using a gradient of difficulty during reading instruction one that allows beginner readers to work their way up a continuum of difficulty in book levels as they gradually learn to build systems of strategic action for reading and writing.

The text gradient used in Mihlali's intervention was based on Fountas and Pinnell's levelling system as outlined below in Table 1. As mentioned, the books are organised on a continuum of difficulty. Whereas beginner or emergent level books have many supportive structures, books at the transitional level contain varied sentence patterns, literary language, specialised vocabulary for some topics and illustrations that provide low to moderate support.

Table 1. Fountas and Pinnell developmental stages and book levels up to level I

\begin{tabular}{|l|c|c|c|c|c|c|c|c|c|}
\hline $\begin{array}{l}\text { Developmental } \\
\text { stages }\end{array}$ & Emergent & \multicolumn{9}{|c|}{ Early } & \multicolumn{2}{|c|}{ Transitional } \\
\hline Book levels & A & B & C & D & E & F & G & H & I \\
\hline
\end{tabular}

\section{APPLYING THEORY TO PRACTICE: THE INTERVENTION}

The instructional implications of applying the abovementioned theory and principles to an effective intervention for Mihlali can be summarised as follows:

Before the intervention, Mihali had been making slow progress in reading and had been falling further and further behind grade level expectations. In order to become an averageprogress reader, he would have to make faster progress than the average learner in his grade 
level. This appears to be a contradiction, but as discussed above, a number of important factors helped accelerate his rate of progress. First, his reading behaviour was assessed using a running record. A running record is a systematic assessment tool that helps educators closely observe and analyse reading behaviour, for example, how the reader is using semantic, syntactic, graphophonic cues, visual cues, and how the reader is monitoring and selfcorrecting. Then he received one-to-one instruction that started with his strengths and that helped him maintain continuous progress by keeping instruction in line with how his learning changed over time. Third, he was given ample opportunities to read 'little books' and write texts at an appropriate level of difficulty. As mentioned earlier, the use of 'little books' fosters comprehension and develops cognitive flexibility (Block \& Duffy, 2008; Clay, 2001). From the start, his understanding of what reading entails was supported by a sense of story that allowed him to constantly check that he comprehended what he read.

Keeping Clay's (1993: 8) admonitions in mind, no time was wasted by diverting his attention away from continuous texts or by involving him in unnecessary activities. He was not expected to work through a preconceived sequence of step-by-step learning. Rather, he engaged in problem-solving new and interesting texts. Supportive teaching, using the Reading Recovery framework, which is outlined below, enabled him to learn about letters, sounds and spelling patterns in the context of reading and writing continuous texts. The goal of instruction was to make him aware that he could initiate and use a variety of reading strategies to construct meaning. Clay (1991a: 4) describes strategies as general processes, such as selfmonitoring and searching for cues that help learners develop independent, self-generating systems of learning. Supportive teacher-learner interactions focused Mihlali's attention on constructing meaningful messages from text, rather than on practising separate skills, which have limited utility and which do not foster comprehension (Gnagey Short, 1991: 100).

Moving from the levels of theory and approach (Richards \& Rodgers, 2001) into actual instruction, I adopted a tutoring framework that is outlined in Reading Recovery (Clay, 1993: 16-17) and which includes the following activities:

- Rereading two or more familiar books.

- Rereading yesterday's new book and taking a running record. By using a text gradient and taking regular running records, I was able to record and monitor Mihlali's progress over time (See Table 2).

- Letter identification and word-level work.

- Writing a story (including hearing and recording sounds in words).

- Cut-up story to be rearranged.

- New book introduced.

- New book attempted.

In addition, after each lesson I gave Mihlali a take-home book that he could read and use to build a home library. I also gave him a blank book and stationery so that he could draw and write about events that interested him. Given that I could not provide daily lessons, which could diminish the power of the intervention to effect change, I enlisted the help of his mother to supplement his weekly lessons by ensuring that he read and wrote regularly at home. 
Table 2. Example from Mihlali's intervention record, showing his progress through book levels.

\begin{tabular}{|l|l|l|l|l|l|}
\hline Date & Week & Lesson & $\begin{array}{l}\text { Book } \\
\text { level }\end{array}$ & Book title & $\begin{array}{l}\text { Observation using } \\
\text { running records: } \\
\text { Accuracy \% }\end{array}$ \\
\hline $21 / 05$ & 1 & 1 & A-1 & In the Park & $\begin{array}{l}\text { No 1-to-1 matching. } \\
\text { Unable to read } \\
\text { beginner level books. }\end{array}$ \\
\hline $28 / 05$ & 2 & 2 & A-2 & Frog Food & \\
\hline $04 / 06$ & 3 & 3 & A-3 & The New Puppy & $98 \%$ \\
\hline $11 / 06$ & 4 & 4 & A-4 & Friends & \\
\hline $18 / 06$ & Teacher not available & B-5 & $\begin{array}{l}\text { Sam and Pappa } \\
\text { Too Much Stuff }\end{array}$ \\
\hline $25 / 06$ & 5 & 5 & B-6 & C-7 & Ant Can't \\
\hline $02 / 07$ & 6 & \multicolumn{7}{|l|}{ School Holiday } \\
\hline $16 / 07$ & 7 & 7 & C-8 & Eggs & $95 \%$ \\
\hline $23 / 07$ & 8 & 8 & $\begin{array}{l}\text { C-8 } \\
\text { C-9 }\end{array}$ & Where Things Grow & $100 \%$ \\
\hline
\end{tabular}

Mihlali's intervention continued weekly until 10 November. By that time he had had 17 lessons and he was just beginning to read books at the transitional level. Most importantly, he was using meaning, language structure and visual information to monitor and problem-solve texts.

The next section briefly describes some of the data and anecdotal information I gathered through systematic observation of Mihlali's literacy learning, the instructional decisions I made and the progressive changes that took place regarding his literacy behaviours from the start to the end of the intervention.

\section{MAKING A DIFFERENCE: IMPLEMENTING THE INTERVENTION}

Mihlali started his lessons towards the end of May. As mentioned earlier, his baseline assessment revealed that he did not understand what it means to read text. This was typical of many instructionally disadvantaged learners that I had worked with in the past, who displayed avoidance behaviours such as fidgeting, staring at the ceiling or trying to search their memories instead of engaging with the print, or who practised ineffective behaviours such as 'reading the pictures', memorising, rote recitation, sounding out and copying. Their learning needs were not being met by their instructional programmes. Based on my experience, I attribute this to reading programmes that focus on letter-sound correspondences at the expense of teaching comprehension strategies. Most worrying of all, these reading programmes were teaching children to practise errors and to build 'habits of responding upon this poor foundation' (Clay, 1991a: 214). These children had developed faulty concepts about reading. They reminded me of a troubling conversation I once had with a teacher who sent a struggling Grade 3 reader to me with the words: 'He doesn't know what's going on'.

As mentioned, I worked from an established body of research which indicates that reading difficulties can be overcome through effective interventions (Clay, 1991b, 2006; Fountas \& 
Pinnell, 2009; Weaver, 1998; What Works Clearinghouse, 2001-2016). Evidently, Mihlali's classroom programme was not preparing him to make adequate progress. He needed an instructional approach that was different to the instruction he had been receiving up to this point in time, one that helped him build effective reading strategies and that prompted him to understand what he was reading. From the start, it was vital to guarantee success, build his confidence and engender reading enjoyment. Reading is an emotional experience (Block \& Parris, 2008; Lyons, 2003). Therefore, it was vital to create an emotionally risk-free environment and eliminate any fear of failure.

To motivate and enable him to read, I gave him high-quality 'little books' that were written with the aim to foster comprehension and engage children in fiction and informational texts. Table 1 explains the levelling system I used and Table 2 contains the titles and levels of the books I used at the beginning of the intervention. The choice of texts for teaching reading is critical, because text characteristics influence children's expectations and some books are more enabling than others. Therefore, I took great care in selecting books according to definite research-based criteria (Clay, 1991a; Fountas \& Pinnell, 2010; Petersen, 1991). For example, the beginning reading books I selected contained at least three sources of predictability: meaningfulness in terms of real life experiences, repetitive sentence structures and a close match between the text and the illustrations. These sources of predictability allowed Mihlali to behave like a reader from the start (Clay, 1991a: 183). In addition, each of the 'little books' I used had separate stories that could be read in one sitting. As outlined in Table 2, these books were organised along a finely-graded continuum of text difficulty.

The text gradient provided a ladder of support that enabled Mihlali to progress from reading beginner level texts to reading more difficult texts with increasing independence. Working with a text gradient allowed me to bolster his confidence by selecting books that he could be taught to read from the start of our first lesson. Each level of the gradient contained six or more books of the same difficulty, which allowed me flexibility in choosing books to suit Mihlali's developing learning needs. Having a variety of books at each level ensured that he had to engage in reading 'work' and could not rely only on memory. However, even wellwritten books will not by themselves teach children to read. Children who have fallen behind in reading need the most accelerative instructional framework possible (Pinnell et al., 1991: $5)$.

As mentioned earlier, to achieve the goal of accelerated learning I used the Reading Recovery framework. Our early lessons consisted of co-reading many interesting 'little books' with supportive features such as repetitive patterns and matching illustrations. Mihlali very quickly picked up the pattern of these beginner books and once he understood that he could use the syntax aided by illustrations and his own experiences to create meaning, his confidence grew and he started to enjoy reading. Having discovered that there was a logic to the reading task that he could tap into, he began to try out reading behaviours he thought he was not allowed to use, such as looking at the pictures to assist text reading, searching and cross-checking cues, understanding that he was allowed to make errors and that rereading and self-correction were important monitoring behaviours. As he made progress, his confidence grew and his attitude to reading became positive. Given the bidirectional relationship between student attitudes toward reading and their reading achievement, this signalled an encouraging turning point in his progress (PIRLS, 2011; Surip, 2016).

During the first few lessons, Mihlali soon became keen to read beginner level books in English, but he hardly spoke. He is an isiXhosa speaker, and because his oral responses were 
minimal, I was not sure how much English he knew or understood. In dealing with this uncertainty, I was guided by the notion that comprehension precedes production (Krashen \& Terrell, 1983). I assumed that the illustrations, written text and other supportive features in the book assisted him to produce the language he needed for reading in English. However, I could not assume that he had access to this knowledge for constructing a conversation. In reading, he had access to the English words in the text to help him construct a sentence. From my experience with my grandchildren, I knew the power of quality stories to engage minds from a very young age, even when adults do not know what parts of a story they understand and engage with. I did not want to push him too hard and create anxiety, so my approach was to continue speaking to and reading with him, much the same way as I do with my grandchildren, assuming that he was in the process of actively constructing his own language competences and that he would gain confidence to speak English over time.

Based on the view that reading and writing are reciprocal processes (Clay, 2001; Rodgers, 2008; Scharer, 2008), we wrote messages cooperatively in every lesson. Most of these early messages were based on the texts he read, because they provided easy access to words, topics and language. Writing provided him with many opportunities to say, hear and record the sounds in his own speech, and to form links between speaking, writing and reading. I also supported his early attempts to write by sharing the pen with him, showing him how to use an alphabet chart and helping him find the words he wanted to write in the books he read. At first, the topics he wrote about were based on the books he read during the lesson (see Figure 1). He typically wrote a few short sentences, making use of the repetitive sentence patterns used in the books to support his writing.

\section{The cow wakes up. \\ The horse wakes up. \\ The pig wakes up. \\ Mihlali wakes up. \\ Nozi wakes up. \\ Figure 1: Sample of Mihlali's first writing based on the book 'Waking Up'}

As the lessons progressed, the message and language quality of his writing improved and he moved away from using repetitive sentence patterns to successful composition of his own ideas and preferences: I like to play soccer everyday! I like my books. My best book is Too Much Stuff. By the middle of the intervention he was writing short, one- to two-paragraph stories based on his experiences (see Figure 2).

I went to the beach with Jacob and zief and esther. I jumped in the water and got full off sand. I ate ice cream. I went home in the train.

\section{Figure 2: Personal story based on experience}

He surprised me by drawing his first picture (something he had not done during our sessions even though I encouraged him to draw). I took this as an indication that he was engaging emotionally and personally with topics that interested him. 


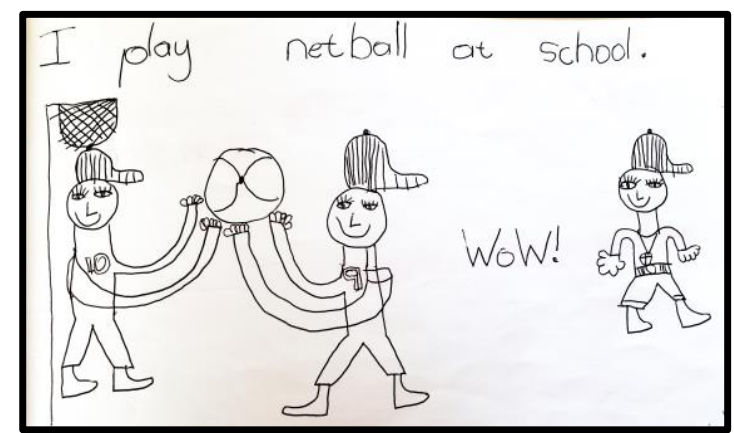

Figure 3: Mihlali's drawing

However, even though I had encouraged Mihlali to draw, I only recently became more aware of the significance of art in education as a means of securing 'deep and diverse forms of meaning' in children's lives (Eisner, 2001: 313). Eisner (2001: 310) puts forward the thesis that 'the arts are cognitive activities ... that make unique forms of meaning possible.' She argues that meanings secured through the fine arts require forms of artistic literacy, without which meaning and expression are impeded. Likewise, Loring (2001: 332) states that the arts build literacy among children and help them develop intuition, reasoning, imagination and unique forms of expression and communication. Without these skills and dispositions, 'children are unlikely to write - not because they cannot spell, but because they have nothing say' (Eisner, 2001: 315). As such, Eisner (2001: 315) argues that the fine arts should not be treated as 'mere diversions from the important business of education'. Rather they should be viewed as 'essential resources'. Yet, in many schools, art seems to be one more indicator of standardisation. Often classroom walls are lined with children's artworks that all look the same, indicating perhaps that neatness and conformity take priority above uniqueness and imagination.

By the time we reached his third lesson, Mihlali was reading a number of level A fiction and nonfiction books fluently and with comprehension. He knew all the letters of the alphabet and he was actively building up a core set of words he could write independently, but he still was not speaking to me in English.

I was therefore very surprised when, on the 11 June (I remember it exactly), he came sliding into the learning venue in shiny black shoes, his arms stretched above his head in glee and announced: 'I am so excited!' That was the first English sentence he spoke to me.

Once he overcame his confusions about what reading entails, Mihlali started making fast progress. As we progressed through the lessons, I observed with satisfaction how he was beginning to fit the puzzle pieces of his prior knowledge and new learning together in a coherent whole. His running records showed that he was monitoring his own reading, attempting to solve unknown words by searching for and cross-checking cues, rereading (R) and self-correcting (SC) his errors (See Figure 4). Figure 4 shows that he substituted potatoes for carrots and pumps for pumpkin, but noticed both his errors and self-corrected. He was using knowledge instead of memorising it. 


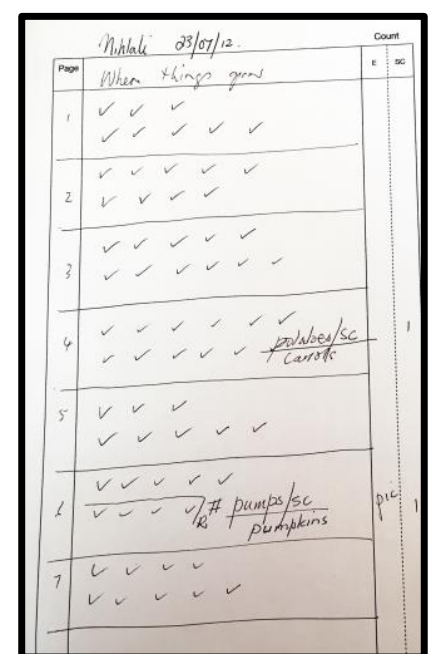

\section{Figure 4: Running Record with self-corrections and rereading}

His mother proudly reported: 'When Mihlali's friends come to visit, he fetches his take-home books - he keeps them locked in a cupboard - sits cross-legged on the ground, spreads his books in front of him, and tells his friends: "Pick any one of them, I can read them all!" The other mothers are jealous! They also want their children to read like Mihlali.' Nozi's snippet of conversation reveals the desire children (and their parents) have for books to read for pleasure. It also highlights, once again, the scarcity of books and the almost 'bookless culture' many South African children face both in and out of school.

Mihlali's newfound confidence and sense of self-efficacy were obvious. He starting speaking English spontaneously, interacting with the books and relating events he read about to the events in his own life. For example, after reading a story about a boy taking his dog for a walk he commented: 'I like to walk with George (a family dog) and Jake and Zief!' (significant others). He read level F-H books fluently, with expression, in a way that showed he understood what he was reading. My notes captured some key moments in his progress:

Journal entries:

16/07. Mihalali read 'Ant Can't' fluently and without errors. After the lesson he surprised me with a spontaneous hug (which brought tears to my eyes). He is starting to communicate freely in English. Today he called me to come and see the rain. When the rain stopped he asked me "Can I go outside and play with George, please?” A sentence spoken confidently and politely in English!

06/10. Mihlali is progressing so well! I'm proud of him! He read the three bears with the expressive qualities of oral speech, speaking in Papa Bear's loud and low voice and in Baby Bears high-pitched voice in a way that reflects the meaning of the story. After the lesson, he asked me for last week's take-home book, saying I never gave him one to take home. Later, Nozi also reminded me not to forget his take-home books. Their hunger for books, even little black and white books struck me. It contrasted sharply with the way some of us take books and literacy for granted.

13/10. Mihlali is becoming 'chatty'. I am having far more interaction with him in English about daily events and books. His confidence is apparent. After the lesson, he announced: "Today's lesson was EASY!"

\section{Figure 5: Observational notes taken during the intervention}

It was nearing the end of the year. Mihlali had attended 17 lessons and read 60 'little books', ranging from beginner to transitional levels (level A to level $\mathrm{H}$ ). He had progressed from not being able to read beginner level books to a transitional stage in his reading. 
His family and I were concerned that the good progress he was making would be hindered by the ineffective reading curriculum, overcrowding and lack of resources in his current school. There is an established relationship between resources and reading achievement (PIRLS, 2006, 2011). Significantly, the PIRLS (2006) database showed that learners in well-resourced schools scored almost 100 points higher than those in schools with inadequate instructional materials. It should therefore be a matter of national concern that only a fifth of learners in South Africa are in schools that are not affected by a shortage of instructional materials, which means that many children spend hours copying content from the blackboard, which severely reduces time for engaged learning (Global Education Monitoring Report, 2016:1).

In addition to these concerns, on its own Mihlali's reading intervention would not be sufficient to ensure his continued progress. He needed a rich school curriculum and excellent teaching throughout his school career. After considering these factors, we decided to move him to a school with better working conditions, instructional resources and facilities. However, his acceptance at that school depended on him passing a grade level reading test. The pending reading test put me under pressure, and I started skipping to higher book levels in the remaining lessons. Mihlali regressed to using distracting tactics. Realising that I was pushing him too hard, I opted for consolidating his reading by returning to easier level texts to build his confidence before the reading test. My notes documented this stage and my final journal entries disclose the results of the reading test (Figure 6).

Journal entries:

10/11. Go back to easier titles. Focus on reading confidence, fluency and vocabulary building. Work on word solving strategies to help him tackle unfamiliar words in more difficult texts.

21/11. Nozi phoned me today to say that Mihlali had passed his reading test and had been accepted at the new primary school next year!!

Figure 6: Observational notes taken at the end of the intervention

\section{CONCLUSION}

The last entry in Figure 6 was made five years ago. During the following years, I have kept track of Mihlali's progress via his mother. Thus far, he has maintained grade level and has passed Grade 5 without further reading interventions, which underscores the value of early intervention, before children have accumulated years of reading failure.

In this article I have discussed a theoretical model that is grounded in field research on successful learners. Because Mihlali's story is not an isolated case, I have shared my some of my experiences in implementing an instructional framework based on this model. Some of the necessary features of this framework include

- increasing the amount and time beginner readers have to read and write continuous text;

- focusing instruction on readers' constructive problem-solving, monitoring and selfcorrecting behaviours rather than on specific bits of information that are presented in isolated ways;

- using the most effective texts that are at an appropriate level of difficulty;

- not wasting valuable teaching time on activities the child does not have to learn; and 
- questioning assumptions that may stand in the way of helping children achieve accelerated progress.

I hope that examining the essential features of this instructional framework could help other teachers prevent the problems evident in Mihlali's story.

\section{ENDNOTE}

1. Makhulu is isiXhosa for Granny.

\section{REFERENCES}

BLOCK, C \& G DUFFY. 2008. Research on teaching comprehension: Where we've been and where we're going. In C Block \& S Parris (Eds), Comprehension instruction: Researchbased best practices. New York: Guilford Press. 19-37.

BLOCK, C \& S PARRIS. 2008. Using neuroscience to inform reading comprehension instruction. In C Block \& S Parris (Eds), Comprehension instruction: Research-based best practices. New York: Guilford Press. 114-126.

BOLSTAD, R, J GILBERT, S MCDOWALL, A BULL, S BOYD \& R HIPKINS. 2012. Supporting future-oriented learning and teaching: A New Zealand perspective. New Zealand: Ministry of Education.

CAINE, R. 2008. How neuroscience informs our teaching of elementary students. In C Block \& S Parris (Eds), Comprehension instruction: Research-based best practices. New York: Guilford Press. 127-141.

CARTWRIGHT, K. 2008. Cognitive flexibility and reading comprehension: relevant to the future. In C Block \& S Parris (Eds), Comprehension instruction: Research-based best practices. New York: Guilford Press. 80-100.

CLAY, M. 1991a. Becoming literate: The construction of inner control. Auckland: Heinemann.

CLAY, M. 1991b. Reading Recovery surprises. In D Deford, C Lyons \& G Pinnell (Eds), Bridges to literacy: Learning from Reading Recovery. Portsmouth: Heinemann. 55-74.

CLAY, M. 1993. Reading Recovery: A guidebook for teachers in training. Auckland: Heinemann.

CLAY, M. 2001. Change over time in children's literacy development. Auckland: Heinemann.

CLAY, M. 2002. An observation survey of early literacy achievement (2nd ed.). Auckland: Heinemann.

CLAY, M. 2005. Literacy lessons designed for individuals. Part one: Why? When? And How? Auckland: Heinemann.

CLAY M. 2006. Literacy lesson designed for individuals. Part two: Teaching procedures. Auckland: Heinemann.

CLAY, M. 2010. What changes in writing can I see. Rosedale: Pearson.

COSTA, A. 2001. Habits of mind. In Developing minds: A resource book for teaching thinking (3rd ed.). Alexandria:ASCD. 80-86.

DEFORD, D. 1991. Using reading and writing to support the reader. In D Deford, C Lyons \& G Pinnell (Eds), Bridges to literacy: Learning from Reading Recovery. Portsmouth: Heinemann. 77-96.

EISNER. E. 2001. The role of the arts in cognition and curriculum. In Developing minds: A resource book for teaching thinking (3rd ed.). Alexandria:ASCD. 310-316.

FOUNTAS, I \& G PINNELL. 2006. Marie M. Clay: Demonstrating that the world can be. 
Language Arts, 83(4):364-370.

FOUNTAS, I \& G PINNELL. 2009. Leveled literacy intervention. Portsmouth: Heinemann.

FOUNTAS, I \& G PINNELL. 2010. A guide to benchmark assessment system 1. Portsmouth: Heinemann.

GLOBAL EDUCATION MONITORING REPORT, 2016. Policy Paper 23. Available from: https://en.unesco.org/gem-report [Accessed: 15 August 2016].

GNAGY-SHORT, K. 1991. Literacy environments that support strategic readers, In D Deford, C Lyons \& G Pinnell (Eds), Bridges to literacy: Learning from Reading Recovery. Portsmouth: Heinemann. 97-118.

HORNSBY, D. 2000. A closer look at guided reading. Armadale Vic: Eleanor Curtain.

KRASHEN, D \& T TERRELL. 1983. The natural approach: Language acquisition in the classroom. Available from: Amazon.com [Accessed: 20 November 2016].

LORING. R. 2001. Music and skillful thinking. In Developing minds: A resource book for teaching thinking (3rd ed.). Alexandria: ASCD. 332-336.

LYONS. C. 2003. Teaching struggling readers: How to use brain-based research to maximize learning. Portsmouth: Heinemann.

MCCARRIER, A, G FOUNTAS \& I PINNELL. 2000. Interactive writing. Portsmouth: Heinemann.

NAIR. P. 2017. The attention myth: Why paying attention in class is overrated. Available from: www.edutopia.org [Accessed: 15 November].

NATHANSON, R. 2011. Texts for guided reading: Selecting books with an appropriate gradient of difficulty. Mousaion, 29(3):284-299.

PETERSEN, B. 1991. Selecting books for beginning readers. In D Deford, C Lyons \& G Pinnell (Eds), Bridges to literacy: Learning from Reading Recovery. Portsmouth: Heinemann. 119-138.

PINNELL, G, M FRIED \& R ESTICE. 1991. Reading Recovery: Learning how to make a difference. The Reading Teacher, 43:282-295.

PINNELL, G \& I FOUNTAS. 2011. Literacy beginnings: A prekindergarten handbook. Portsmouth: Heinemann.

PLOWRIGHT, D. 2011. Using mixed methods: Frameworks for an integrated methodology. London: SAGE.

PROGRESS IN INTERNATIONAL LITERACY STUDY (PIRLS). 2006. International report. Available from: www.pirls.bc.edu/pirls2006/intl_rpt.html [Accessed: 20 November 2006].

PROGRESS IN INTERNATIONAL LITERACY STUDY (PIRLS). 2011. International report. Available from: https://timssandpirls.bc.edu/pirls2011 [Accessed: 10 August 2011].

RICHARDS, J \& T RODGERS. 2001. Approaches and methods in language teaching (2nd ed.). New York: Cambridge University Press.

ROGERS, E. 2008. Write now! Don't wait to teach struggling readers about. In P Scharer \& G Pinnell (Eds), Guiding K-3 writers to independence: The new essentials. Columbus, OH: Ohio State University. 183-198.

RUMELHART, D \& J MCCLELLAND. 1986. Parallel distributed processing. Vol 1: Foundations. Cambridge, MA: MIT Press.

SCHARER, P. 2008. Talking about books to learn the writer's craft. In P Scharer \& G Pinnell (Eds), Guiding K-3 writers to independence: The new essentials. Columbus, $\mathrm{OH}$ : Ohio State University. 121-130.

SURIP, R. 2016. The relationship among self-concept, reading attitude and reading comprehension achievement of single parented students of public junior high schools in district of Ilir Barat I Palembang. Journal of English Literacy Education, 3(1):12-26. 
WEAVER, C. 1994. Reading process and practice: From socio-psycholinguistics to whole language (2nd ed.). Portsmouth: Heinemann.

WEAVER, C. 1998. Reconsidering a balanced approach to reading. Illinois: National Council of Teachers. 11-74.

WHAT WORKS CLEARINGHOUSE, 2016. What Works Clearinghouse documents Reading Recovery's scientific research base. Available from:

https://readingrecovery.org/reading-recovery/research/what-works-clearinghouse [30 November 2016].

\section{BIOGRAPHICAL NOTE}

Dr Renee Nathanson is a lecturer in the Division of English at Stellenbosch University. Her main research interests are future oriented teaching and learning, literacy instruction and the use of digital technologies in education. Email address: $\underline{\text { rrn@sun.ac.za }}$ 